\title{
The Influence of Motoric Ability Development on Child Aggressive Behavior is Reviewed from Social Class Level
}

\author{
Evania Yafie \\ Early Childhood Education, State University of Malang, Indonesia \\ rosevonia@yahoo.com
}

\begin{abstract}
This study aims to analyze and improve the relationship of motor development of children on aggressive behavior, either directly or indirectly through the social class of parents as intervening variables. The research method used is descriptive quantitative with explanatory method. The sample in this study was taken by random sampling technique with 100 children from kindergarten in Malang. Data completion technique using questionnaires, while the data analysis techniques used are descriptive and inferential statistics with path analysis. The results showed that there was a positive and significant influence of children's gross motor development against aggression. There is no indirect influence of gross motor development of children against aggression through social class of parents as intervening variable.
\end{abstract}

Keywords: motoric development, aggressive behavior, social class of parents, children

\section{INTRODUCTION}

Based on six aspects of development that exist in early childhood, a child's physical motor development is of particular concern in a research study, because the process of physical growth of children's motor can affect their lives in the future (Papalia, Olds, \& Feldman, 2004; Zulkifli, 2001; Werner, 2006). The results also show that there is a causal relationship between the physical development of the child's motor with other developments such as intellectual or cognitive development of motor as well as motor influence on language development (Oden \& Asher, 1977; Schneider, 2000).

Motor development includes coarse and fine motor (Sumantri, 2005). Rough motor is a body movement that uses large muscles or most or all of the limbs that are affected by the maturity of the child itself, such as the ability to sit, kick, run, up and down stairs and so forth. While fine motor is a movement that uses the smooth muscles or certain parts of the body, which is influenced by opportunities to learn and practice such as the ability to move objects from the hand, doodling, arranging blocks, cutting, writing and so forth. Both of these abilities are essential so that the child can develop optimally (Kanioglou, et al., 2005).

The role of motor skills of children is considered very central for life support. Hurlock (2008) Motor development, especially gross motor is one of the most important factors, some influence of motor development toward the constellation of individual development presented by Sadock et al. (2007) through motor skills, the child can amuse himself. Motor development at this age becomes smoother and more coordinated compared to infancy. Children look faster in running and are good at jumping and abilities to keep their balance. The process of refining motor skills, children continue to perform a variety of physical activities that are sometimes informal in the form of a game. In addition, children also engage in formal sports activities such as gymnastics and swimming (Ladd and Kochenderfer-Ladd, 2002).

Early detection of child growth consists of careful monitoring of physical motor growth, cognitive development, psychosocial development. Each developmental parameter has its own stages according to the development of age. The toddler period is a golden age in the developmental range of an individual. At this time, children experience extraordinary growth, both in terms of physical, motor, emotional, cognitive and psychosocial. Child development takes place in a holistic or holistic process. Therefore. The provision of stimulation also needs to take place in a holistic activity (Erwin, 2003; Kostelnik, et al., 2005). Motor development is different in each individual level. Four-year-olds can easily use scissors while others may be over five or six years of age. Certain boys may be able to snack and catch the ball easily while others may only catch large or rolling balls. Similarly, environmental stimulation, nutritional status, race and genetics have an important influence in motor development (Shaffer, et al., 2005; Sigurdsson, et al., 2002).

The study of rough motor relationships with the social development of children, especially in the school environment and playing environment with peers is still quite rarely studied. However, some of the results of existing studies show that there is an influence between motor development, especially motor rough with social development of children (Dunn, et al., 2007; Erwin, 2003; Gulay, 2010; Kostelnik, et al., 2005). Deeper Morrison (2000) reveals that motor development is a sequence of children's learning that focuses on body movement, in which the movement plays an important role in the life of the child especially related to behavior and social life. In order for children to have no problems with their social life, it is necessary to monitor the gross motor development by observing the child's ability to control the balance movement, coordination, environmental awareness, and game playing skills. Williams and Monsma (2007) explain that children's social skills are determined by the quality of physical health, nutrition, child motor, intellectual and psychological even family environment conditions.

The child's social skills are the ability to interact with others in a social context in ways that are socially acceptable and values and at the same time useful to themselves and others (Coolahan, Fantuzzo, Mendez, \& McDermott (2013). Social skills in children include empathy in which children expressing their feelings, generosity or generosity, cooperation and care. The early child begins to have the ability to adapt 
from self-centeredness (egocentric) to cooperative (sociocentric) or sociocentric (cooperative) Want to pay attention to the interests of people).

Social skills in children in forming peer groups can develop children's social activities, children begin to work together, recognize roles in groups, understand others, and make friends (Williams and Monsma, 2007). According to Gulay, Seven and Damar (2010) explains that children's social skills can be detected using eight subvariables, namely: (1) pro-social behavior; (2) aggression; (3) asocial behavior; (4) exclusion affected; (5) fear and Anxiety; (6) hyperactivity and distractibility; (7) victimization; and (8) peer acceptance. This study will only focus on aggression or aggression variables. Aggression is an individual behavior that is intended to injure or harm other individuals who do not want the behavior to come (Baron, 2003). Children who have good physical conditions, especially good rough motor physical and perfect in its development, contribute to the emergence of the character of aggression in children although not too dominant (Erwin, 2003). The high level of aggression that is owned by the child is dominated by personality factors, but the motor physical factors become a means in achieving that goal, because without a good physical motor a child will not have the ability and confidence to do aggression because it will result in retaliation from his friend (Ladd and Kochenderfer-Ladd, 2002).

Gallahue and Ozmun (2006); Ulrich, (2000), rough motor development of children develops optimally occurs at the age of 2-6 years. During this period the basic patterns of motor development begin to form from simple movements into complex movements. Ozer and Ozer (2004) explain if the aspects of development go according to the level of development it will not interfere with other aspects of development will even greatly support the development of children one of them related to confidence of children. The correlation between cognitive development and development. Davies (2000) states that rough motor skills affect the self esteem and peer relations of the children. Studies show that children with inadequate rough motor skills can be socially isolated in their peer group. Motor skills and social skills during preschool are areas that affect the general development of children in the long run (For et al., 2001). The results of other studies show that children with delays in motor development will have an impact on other aspects of development such as language development, academic achievement, adjusting to the environment of friends impacting social skills (Gabbord, 2006; Gallahue and Ozmun, 2006).

The relationship of gross motor development and social development of children can also be influenced by the social class of the family. Williams and Monsma (2007) explain that children's social skills are determined by the quality of physical health, nutrition, child motor, intellectual and psychological even family environment conditions. Family environment conditions that can affect the development of children are social class or social status. Classification of social class in research using social position index (ISP) as stated in journal Mihic and Culina (2006) which of course modified and adapted to this research. Classification of social class using an ISP is classification of social class based on three determinant factors, namely work, education, and income. Connell, \& Prinz, (2002) describe the social conditions of the parent class will have an impact on the fulfillment of nutrition, access to health facilities and facilities, consumption, and access to the quality of education so that it can affect the social development of children.

Relating to the context of the researcher took the location of research in the city of Malang precisely in children aged 5-6 years in kindergarten Se-Gugus 8 District Lowokwaru Malang. The reason, researchers chose Palm Kids as the object of research because the kindergarten is one kindergarten in the housing complex Elite Araya Malang. Most children come from families with higher social class. However, the interesting phenomenon is that Kindergarten $\mathrm{K}-8$ Cluster of Lowokwaru Sub-district always provides scholarships to underprivileged children, especially those residing in residential areas or families working in the housing. They place 10-15 seats of scholarship to these underprivileged children and mix them with other students. So from 3 grades TK B one class of them is mixed class. Based on this background, the researcher wanted to focus the discussion on "The Influence of Rough Motor Development against Child Aggression Where Social Class of Parent as Variable Intervening (Study In children aged 5-6 years in kindergarten for 8 sub districts of Lowokwaru Malang). The purpose of this research is: (1) to analyze the direct influence of children's gross motor development toward aggression; and (2) to analyze the indirect influence of children's gross motor development toward aggression through social class of parents as intervening variable.

\section{Research Design}

\section{METHODS}

In this research, the writer uses a descriptive method with quantitative approach. Bungin (2008) argues that quantitative research with descriptive format aims to explain, summarize various conditions, various situations, or various variables that arise in the community that became the object of research based on what happened, generally this study using inductive statistics to analyze research data. In addition to descriptive formats, the type of research to be used in this study is exploratory research or research directed to explain a situation or the situation (Notoatmodjo, 2005). Type explanatory research is the same as the correlation, where in this method described the relationship or influence between variables studied. In relation to the objectives of the study, this study uses a survey method, ie, the research obtained from sampling of a population and using questionnaires and observation or observation sheets as a basic data collection tool (Singarimbun, 2006). This explanatory research aims to find out the direct and indirect influence of children's gross motor development variable toward social development where the social class of parents as intervening variable. 
Table 1

Variable Operationalization of Research Indicators

\begin{tabular}{|c|c|c|c|}
\hline No & Variable & Indicator & Reference \\
\hline 1 & $\begin{array}{l}\text { Gross motor skills } \\
\text { child roughly 5-6 } \\
\text { years old } \\
\text { (X) }\end{array}$ & $\begin{array}{l}\text { 1. Walk with the heels of your feet, on your toes, jump up irregularly, and run well. } \\
\text { 2. Standing on one leg for } 5 \text { seconds or more, controlling the balance, standing on a } 4 \text {-inch } \\
\text { beam }(10.16 \mathrm{~cm}) \text {, but having difficulty walking a } 5 \mathrm{~cm} \text { wide beam without seeing the foot } \\
\text { 3. Down stairs with legs alternately, can estimate foot ground. } \\
\text { 4. Can jump with adequate tempo rules and be able to play games that require quick reaction } \\
\text { 5. Begin to coordinate his movements when climbing or rolling on a small trampoline (screen } \\
\text { cloth in the range to accommodate acrobats) } \\
\text { 6. Shows increased endurance in longer periods, sometimes too excited and loses self-control } \\
\text { in group activities }\end{array}$ & $\begin{array}{l}\text { STPPA Permen } \\
137 \text { and } 146\end{array}$ \\
\hline \multirow[t]{2}{*}{2} & \multirow[t]{2}{*}{$\begin{array}{l}\text { Child social } \\
\text { development } \\
\text { (Y) }\end{array}$} & $\begin{array}{l}\text { Behaviour (Y1) } \\
\text { 1. Have the ability to share the taste } \\
\text { 2. Have the ability cooperation } \\
\text { 3. Has the ability to contribute } \\
\text { 4. Have a concern } \\
\text { 5. Have attention }\end{array}$ & $\begin{array}{c}\text { Baron \& Byrne } \\
(2005)\end{array}$ \\
\hline & & $\begin{array}{l}\text { Behavior of Physical Aggression (Y2) } \\
\text { 1. Direct active physical aggressive behavior } \\
\text { 2. Indirect physical actual aggressive behavior } \\
\text { 3. Direct passive physical aggressive behavior } \\
\text { 4. Indirect passive physical aggression behavior } \\
\text { 5. Direct } \\
\text { 6. Indirect physical actual aggression behavior } \\
\text { 7. Direct passive physical aggressive behavior } \\
\text { 8. Indirect passive physical aggression behavior }\end{array}$ & Erwin (2003) \\
\hline
\end{tabular}

Table 2

Variable Social Class ( Index of Social Position Research)

\begin{tabular}{|c|c|}
\hline \multicolumn{2}{|l|}{ Employment Scale (Weight Value 4) } \\
\hline Description & Score \\
\hline Part time worker & 10 \\
\hline Uneducated workers (domestic servants, gardeners, casual workers) & 9 \\
\hline Small and non-permanent farmers & 8 \\
\hline Retirees who are solely dependent on benefits & 7 \\
\hline Skilled workers (haircuts, factory workers, secretaries, and other wealthy classes) & 6 \\
\hline Medium manger, supervisor, small business owner, government official & 5 \\
\hline Teachers, lecturers, military, police and other civil servants & 4 \\
\hline Upscale professionals such as Doctors, artists, renowned artists, renowned painters, famous designers) & 3 \\
\hline Top managers, medium business owners (10-20 employees) & 2 \\
\hline High-ranking corporate executives, large business owners, senior officials (ministers, parliament) & 1 \\
\hline \multicolumn{2}{|l|}{ Education Scale (Weight Value 3) } \\
\hline Education that is being pursued or already taken & Score \\
\hline Never had an education & 10 \\
\hline Elementary School (SD) & 9 \\
\hline Junior High School (SMP) & 8 \\
\hline High School / Vocational School (SMA / SMK) & 7 \\
\hline Diploma 1 (D1) & 6 \\
\hline Diploma 2 (D2) & 5 \\
\hline Diploma 3 (D3) & 4 \\
\hline Strata 1 / Diploma 4 (S1 / D4) & 3 \\
\hline Strata $2(\mathrm{~S} 2)$ & 2 \\
\hline Strata $3(\mathrm{~S} 3)$ & 1 \\
\hline \multicolumn{2}{|l|}{ Education Scale (Weight Value 3) } \\
\hline Total Revenue per Month (IDR) & Score \\
\hline$<1.882 .250$ & 10 \\
\hline 3.764 .500 & 9 \\
\hline 5.646 .750 & 8 \\
\hline 7.529 .000 & 7 \\
\hline $11,293.500$ & 6 \\
\hline 15.058 .000 & 5 \\
\hline 18.822 .500 & 4 \\
\hline 24.469 .250 & 3 \\
\hline 30.116 .000 & 2 \\
\hline$>30.116 .000$ & 1 \\
\hline
\end{tabular}

Source: Mihic and Culina (2006)

Table 3

Classification Techniques Social Class

\begin{tabular}{lc}
\hline \multicolumn{1}{c}{ Social Class Level } & Range Score \\
\hline Upper and upper middle class & $10-27$ \\
Middle class & $28-60$ \\
Lower and Lower Class & $61-100$ \\
\hline \multicolumn{2}{c}{ Sorce Mihi don Culna $(2006)$} \\
\hline
\end{tabular}

Source: Mihic dan Culina (2006) 


\section{Research Variables}

Based on the theories and concepts that have been formulated, can be explained variables, indicators, and items in this study are presented in Table 1. For the purposes of calculation, the score of social class assessment results are then grouped into 3 levels of social class that is upper, middle, and lower class class by referring to the Table 3 .

\section{Population and Sample}

Population is all data that concerns us in a scope and time that we specify. So within the scope of this study, the population in the study were all students kindergarten B-Gugus 8 Lowokwaru District, Malang City, East Java, Indonesia.. Sampling technique that will be used in this research is Random sampling. Random sampling is a method of random sampling of population members into samples (Hidayat, 2007). Using 100 children from Kindergarten Gugus 8 Lowokwaru District, Malang City, East Java, Indonesia.

\section{Research Hypothesis and Research Design}

Research hypothesis is: H1 there is a direct influence on children's gross motor development against aggression; and $\mathrm{H} 2$ there is an indirect effect of gross motor development of children on aggression through social class of parents as intervening variable. Research design illustrated Figure 1.

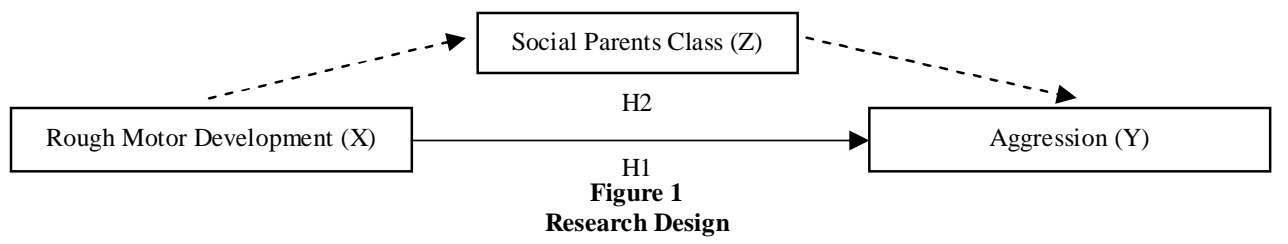

\section{Data Analysis Techniques}

This research uses inferential analysis that is inferential statistic is a statistical technique used to analyze sample data and the result applies to population (Sugiyono, 2010). Based on the hypothesis and the research design, the data collected in this study were analyzed using path analysis technique (path analysis).

\section{RESULT AND DISCUSSION \\ Overview of Research Variables Social Class}

Social class is the distinction of the population or society into the hierarchical classes, in which the class distinction in society is based on the economic, educational, occupational and related factors of a family member with the status of other family members, When the position of the head of the family goes up, then the status of other family members goes up as well. The embodiment of layers or classes of high, medium, or low classes in this study is based on classification of social class using the Index of Social Position (ISP) is a classification of social class based on three determinants of work, education, and income. Description of respondents' revenue (Table 4); respondents education picture (Table 5); and job description of respondents (Table 6).

Table 4

Description of Respondents' Revenue

\begin{tabular}{|c|c|c|c|}
\hline No & Income (IDR) & Amount & Percentage \\
\hline 1 & $>30.400 .000$ & 4 & $4 \%$ \\
\hline 2 & $24.700 .001-30.400 .000$ & 4 & $4 \%$ \\
\hline 3 & $19.000 .001-24.700 .000$ & 8 & $8 \%$ \\
\hline 4 & $15.200 .001-19.000 .000$ & 10 & $10 \%$ \\
\hline 5 & $11.400 .001-15.200 .000$ & 10 & $10 \%$ \\
\hline 6 & $7.600 .001-11.400 .000$ & 13 & $13 \%$ \\
\hline 7 & $5.700 .001-7.600 .000$ & 15 & $15 \%$ \\
\hline 8 & $3.800 .001-5.700 .000$ & 13 & $13 \%$ \\
\hline 9 & $1.900 .001-3.800 .000$ & 17 & $17 \%$ \\
\hline 10 & $<1.900 .000$ & 6 & $6 \%$ \\
\hline & Total & 100 & $100 \%$ \\
\hline
\end{tabular}

Table 5

Respondents Education Picture

\begin{tabular}{clccc}
\hline No & & Education & Amount & Percentage \\
\hline 1 & Not School & 0 & $0 \%$ \\
2 & Primary School & 0 & $0 \%$ \\
3 & Secondary School & 5 & $5 \%$ \\
4 & Senior High School / Vocational High School & 23 & $23 \%$ \\
5 & Diploma 1 (D1) & 13 & $13 \%$ \\
6 & Diploma 2 (D2) & 8 & $8 \%$ \\
7 & Diploma 3 (D3) & 11 & $11 \%$ \\
8 & S1/D4 & 38 & $38 \%$ \\
9 & S2 & 2 & $2 \%$ \\
10 & S3 & 0 & $0 \%$ \\
\hline & & Total & $\mathbf{1 0 0}$ & $\mathbf{1 0 0 \%}$ \\
\hline
\end{tabular}


Table 6

Job Description of Respondents

\begin{tabular}{clcc}
\hline No & \multicolumn{1}{c}{ Type of Work } & Amount & Percentage \\
1 & High corporate executives, large business owners, high officials & 9 & $9 \%$ \\
2 & Top managers, medium business owners (10-20 employees) & 19 & 7 \\
3 & Upscale professionals & 14 & $19 \%$ \\
4 & Teachers, lecturers, military, police and other civil servants & 21 & $1 \%$ \\
5 & Medium manger, supervisor, small business owner, government official & 28 & $21 \%$ \\
6 & Skilled laborers and other wealthy classes & 1 & $28 \%$ \\
7 & Retirees who are solely dependent on benefits & 1 & $1 \%$ \\
8 & Small and non-permanent farmers & 0 & $1 \%$ \\
9 & Uneducated power & 0 & $0 \%$ \\
10 & Part time worker & $0 \%$ & $0 \%$ \\
\hline
\end{tabular}

Table 7

Description of Respondent's Social Class Level

\begin{tabular}{clcccc}
\hline No & \multicolumn{1}{c}{ Social Class Level } & ISP Value & Amount & Percentage \\
\hline 1 & High Social Class & $>28$ & 11 & $11 \%$ \\
2 & Medium Social Class & $29-60$ & 54 & $54 \%$ \\
3 & Low Social Class & $61-100$ & 35 & $35 \%$ \\
\hline & Total & $\mathbf{1 0 0}$ & $\mathbf{1 0 0 \%}$ \\
\hline
\end{tabular}

Table 8

Distribution of Rrespondent Answers to Variables of Aggression Behavior

\begin{tabular}{|c|c|c|c|c|c|c|c|c|c|c|c|c|}
\hline \multirow{2}{*}{ No } & \multirow{2}{*}{ Item } & \multicolumn{2}{|c|}{ SB (5) } & \multicolumn{2}{|c|}{ S (4) } & \multicolumn{2}{|c|}{ CB (3) } & \multicolumn{2}{|c|}{ KB (2) } & \multicolumn{2}{|c|}{ TB (1) } & \multirow{2}{*}{ Mean } \\
\hline & & $\mathbf{F}$ & $\%$ & $\mathbf{F}$ & $\%$ & $\mathbf{F}$ & $\%$ & $\mathbf{F}$ & $\%$ & $\mathbf{F}$ & $\%$ & \\
\hline 1 & Y_PA1 & 1 & $1 \%$ & 20 & $20 \%$ & 28 & $28 \%$ & 43 & $43 \%$ & 8 & $8 \%$ & 2.63 \\
\hline 2 & Y_PA2 & 1 & $1 \%$ & 17 & $17 \%$ & 33 & $33 \%$ & 40 & $40 \%$ & 9 & $9 \%$ & 2.61 \\
\hline 3 & Y_PA3 & 1 & $1 \%$ & 18 & $18 \%$ & 35 & $35 \%$ & 38 & $38 \%$ & 8 & $8 \%$ & 2.66 \\
\hline 4 & Y_PA4 & 1 & $1 \%$ & 6 & $6 \%$ & 40 & $40 \%$ & 48 & $48 \%$ & 5 & $5 \%$ & 2.5 \\
\hline 5 & Y_PA5 & 1 & $1 \%$ & 23 & $23 \%$ & 36 & $36 \%$ & 39 & $39 \%$ & 1 & $1 \%$ & 2.84 \\
\hline 6 & Y_PA6 & 1 & $1 \%$ & 12 & $12 \%$ & 44 & $44 \%$ & 35 & $35 \%$ & 8 & $8 \%$ & 2.63 \\
\hline 7 & Y_PA7 & 1 & $1 \%$ & 27 & $27 \%$ & 34 & $34 \%$ & 35 & $35 \%$ & 3 & $3 \%$ & 2.88 \\
\hline 8 & Y_PA8 & 2 & $2 \%$ & 23 & $23 \%$ & 33 & $33 \%$ & 35 & $35 \%$ & 7 & $7 \%$ & 2.78 \\
\hline \multicolumn{12}{|c|}{ Mean } & 2.69 \\
\hline
\end{tabular}

Table 9

Variable Value Category

\begin{tabular}{ccl}
\hline No & Mean Value & \multicolumn{1}{c}{ Category } \\
\hline 1 & $4.21-5.00$ & Very High / Good \\
2 & $3.41-4.20$ & High / Good \\
3 & $2.61-3.40$ & High enough / Good Less \\
4 & $1.81-2.60$ & Low \\
5 & $1.00-1.80$ & $\mathrm{Bad} /$ Low \\
\hline
\end{tabular}

Table 10

The Gross Motor Development of Children

\begin{tabular}{|c|c|c|c|c|c|c|c|c|c|c|c|c|}
\hline \multirow{2}{*}{ No } & \multirow{2}{*}{ Item } & \multicolumn{2}{|c|}{ SB (5) } & \multicolumn{2}{|c|}{ S (4) } & \multicolumn{2}{|c|}{ CB (3) } & \multicolumn{2}{|c|}{ KB (2) } & \multicolumn{2}{|c|}{ TB (1) } & \multirow{2}{*}{ Mean } \\
\hline & & $\mathbf{F}$ & $\%$ & $\mathbf{F}$ & $\%$ & $\mathbf{F}$ & $\%$ & $\mathbf{F}$ & $\%$ & F & $\%$ & \\
\hline 1 & X_MK1 & 35 & $35 \%$ & 33 & $33 \%$ & 27 & $27 \%$ & 5 & $5 \%$ & 0 & $0 \%$ & 3.98 \\
\hline 2 & X_MK2 & 26 & $26 \%$ & 36 & $36 \%$ & 31 & $31 \%$ & 7 & $7 \%$ & 0 & $0 \%$ & 3.81 \\
\hline 3 & X_MK3 & 28 & $28 \%$ & 41 & $41 \%$ & 21 & $21 \%$ & 10 & $10 \%$ & 0 & $0 \%$ & 3.87 \\
\hline 4 & X_MK4 & 27 & $27 \%$ & 45 & $45 \%$ & 22 & $22 \%$ & 6 & $6 \%$ & 0 & $0 \%$ & 3.93 \\
\hline 5 & X_MK5 & 20 & $20 \%$ & 52 & $52 \%$ & 22 & $22 \%$ & 6 & $6 \%$ & 0 & $0 \%$ & 3.86 \\
\hline 6 & X_MK6 & 19 & $19 \%$ & 52 & $52 \%$ & 26 & $26 \%$ & 3 & $3 \%$ & 0 & $0 \%$ & 3.87 \\
\hline 7 & X_MK7 & 15 & $15 \%$ & 65 & $65 \%$ & 16 & $16 \%$ & 4 & $4 \%$ & 0 & $0 \%$ & 3.91 \\
\hline 8 & X_MK8 & 18 & $18 \%$ & 51 & $51 \%$ & 26 & $26 \%$ & 5 & $5 \%$ & 0 & $0 \%$ & 3.82 \\
\hline 9 & X_MK9 & 24 & $24 \%$ & 56 & $56 \%$ & 17 & $17 \%$ & 3 & $3 \%$ & 0 & $0 \%$ & 4.01 \\
\hline 10 & X_MK10 & 19 & $19 \%$ & 48 & $48 \%$ & 29 & $29 \%$ & 4 & $4 \%$ & 0 & $0 \%$ & 3.82 \\
\hline 11 & X_MK11 & 16 & $16 \%$ & 38 & $38 \%$ & 32 & $32 \%$ & 14 & $14 \%$ & 0 & $0 \%$ & 3.56 \\
\hline \multicolumn{12}{|c|}{ Mean } & 3.86 \\
\hline
\end{tabular}

\section{Assessment of Social Class ISP}

The social class is the distinction of the population or society into the hierarchical classes, which manages the class distinction in that society on the economic, educational, occupational and related factors of a family member with the status of the other, when the head families rise, then the status of other family members go up as well. Based on Table 7, most of the social classes are with the range 29-60 of 54 respondents, range $61-100$ with low social class that is as many as 35 respondents, range $>28$ high social class that is as much as 11 respondents, so it can be concluded that most respondents are in a moderate social class.

\section{Variable of Aggression Behavior}

Based on the observation results can be seen that the behavior of child aggression in the category is quite high because it is in the range 2.61-3.40 with an average of 2.69. The results of observation data seen in 
the following Table 8 and variable value category illustrated Table 9.

\section{Crude Motor Variables}

Based on the observation it can be seen that the gross motor development of children is in the high category with an average of 3.86 because it is in the range of 3.41-4.20. The results of observation data seen in the following Table 10.

\section{Hypothesis Testing \\ Coefficient of Line Influence of Rough Motor Development Against Behavior of Aggression Directly or Indirectly Through Social Status}

The table below illustrates the test results of the effect of gross motor development on aggression behavior directly or indirectly through social status which is presented as follows (Table 11).

Table 11

Summary of Path Coefficients

\begin{tabular}{clccccc}
\hline $\begin{array}{c}\text { Independent } \\
\text { Variable }\end{array}$ & Dependent Variable & $\begin{array}{c}\text { Coefficient of } \\
\text { Beta }\end{array}$ & P-Value & t-count & $\mathbf{r}^{2}$ & Conclusion \\
\hline Gross Motor & Aggression Behavior & 0.730 & 0.000 & 9.016 & 0.453 & Significant \\
Gross Motor & Social status & 0.751 & 0.000 & 6.196 & 0.281 & Significant \\
Social status & Aggression Behavior & -0.005 & 0.034 & -2.156 & 0.045 & Significant \\
\hline
\end{tabular}

Based on the data it can be interpreted as follows:

1. There is a gross motor positive effect on aggression behavior of 0.730 , or the better the child's harsh motor, the higher the aggression behavior. Where the significant influence or consistent because the significance value < from 0.05 and t-count (9.016) $>$ t-table 1660. While based on the results of $r^{2}$ test shows the number 0.453 or the influence contributes $45.3 \%$ and the rest is influenced by other variables;

2. There is a gross motor positive effect on the social status of 0.751 , or the better the gross motor of the child the higher the social status. Where such influence is significant or consistent since the significance value < from 0.05 and t-count (6.196) $>$ t-table 1.660. Whereas based on $r^{2}$ test results showed the number 0.281 or the effect contributes $28.1 \%$ and the rest is influenced by other variables;

3 . There is a negative effect of social status on aggression behavior of -0.005 , or the better the social status of children the aggression behavior is lower. Where such influence is significant or consistent since the significance value $<$ from 0.05 and t-count $(-2.156)>\mathrm{t}$-table 1.660. While based on the test results $\mathrm{r}^{2}$ shows the number 0.045 or the influence contributes $4.5 \%$ and the rest is influenced by other variables.

Through the description of path analysis can be explained the magnitude of the path coefficient on each relationship of two variables, where the relationship has a direct and indirect influence. Direct influence is the influence of independent variables on the influence of the dependent variable directly without going through another variable. The indirect effect is the influence of the independent variable on the dependent variable through another variable.

\section{Coefficient of Line Influence of Rough Motor Development Against Behavior of Aggression Directly or Indirectly Through Social Status}

The results of the calculation of the magnitude of direct and indirect effects are presented in the following Table 12.

Table 12

Test Results Direct and Indirect Relationships

\begin{tabular}{ccc} 
& \multicolumn{2}{c}{ Test Results Direct and Indirect Relationships } \\
\hline Influences of Variabel & Direct Influences & Indirect Influences \\
\hline $\mathrm{X}$ to Y & 0.730 & - \\
$\mathrm{X}$ to Z & 0.751 & $(0.751) \mathrm{x}(-0.005)=-0.003755$ (sign.) \\
\hline
\end{tabular}

Based on the results of the data analysis can be seen that the indirect effect of -0.003755 smaller than the direct influence of 0.730 this proves that social status does not give impact or intervening influence between gross motor development against aggression behavior. Based on the results of the above analysis can be formed the path of direct influence as follows (Figure 2).

Aggression is an individual behavior that is intended to injure or harm other individuals who do not want the behavior to come (Baron, 2003). Berkowitz explains that aggression as any form of behavior that is meant to harm a person both physically and mentally. For Berkowitz the negative feelings posed by a stress can produce a tendency of anger and aggression behavior. Aggressiveness, (Sarwono, 2005) can be influenced by things that can stimulate it, the stimulus or influence of the aggression may come from outside the self (i.e. environmental conditions or group influences) or from the actors themselves (the influence of physical condition and personality). Children who have good physical conditions, especially good rough motor physical and perfect in its development, contribute to the emergence of the character of aggression in children although not too dominant (Erwin, 2003). The high level of aggression that is owned by the child is dominated by personality factors, but the motor physical factors become a means in achieving that goal, because without a good physical motor a child will not have the ability and confidence to do aggression because it will result in retaliation from his friend. (Ladd, and Kochenderfer-Ladd, 2002). 


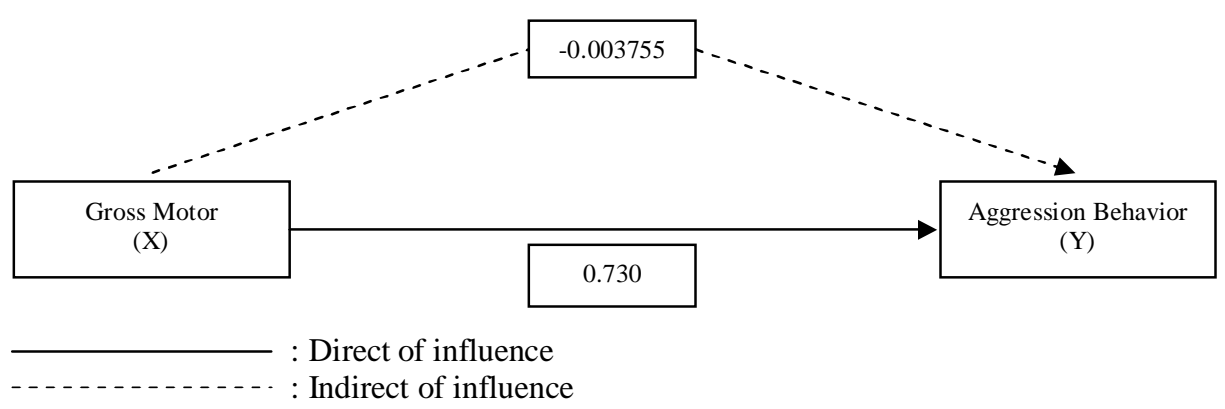

Figure 2

The Direct and Indirect Effects

The results showed that there is a positive and significant effect of gross motor development of children on aggression behavior, this proves that the better or higher the motor development of children's rough, the child tends to be aggression and violence in other children because they have a better physical. There is an indirect effect of gross motor development of children on aggression behavior through the social class of parents as intervening variables, where high social class seen from social status, income and family education can reduce the negative impact of children's motor on aggression behavior.

This is in accordance with the research of Asher, Tinsley and Hymel (2009) which states that children have high curiosity and tend to try something new. But the nature of their curiosity is still opposite to each other's ego so that it appears the nature of winning themselves and do not want to know. Supported by high physical motor they will tend to be aggressive and will even violate their friends when they want something.

\section{Rough Motoric in Children 5-6 Years (Kindergarten B)}

Motors in early childhood are needed, to develop the intelligence of children in the field of language development, cognitive, art and creativity. The motor translation of Gallahue's "motor" in Samsudin (2005) is a biological or mechanical basis that causes a motion. In other words motion (movement) is the culmination of an action that is based on the motor. Motor development at the age of kindergarten is based on activity. Activity of kindergarten children using Physical or Physical activity is $80 \%$.

Rough motor is the ability of gestures that use large muscles, most or all of the rough motor parts in need so that children can sit, kick, run, up and down stairs and so on (Sunardi and Sunaryo, 2007). Rough motor development of the child first than the fine motor, for example the children will first hold objects of larger size than the small size. Because the child has not been able to control the movement of his fingers for fine motor skills, such as make a necklace, cutting and others.

Irianto (2002) states that physical fitness can be grouped into three: (1) statistical fitness; (2) dynamic fitness; and (3) motorized fitness. Sujiono (2007) suggests that elements of physical fitness include strength, endurance, speed, agility, flexibility, coordination, precision and balance. Further Sujiono (2007) states that the movement that arises and occurs in the rough motor is a movement that occurs and involves large muscles of the body, and require considerable energy.

Barrow and McGee (1976) suggest that elements of motor skills consist of: strength, speed, power, endurance, agility, balance, flexibility, and coordination. The same thing is also explained by Mutohir and Gusril (2004) that elements of motor skills include:

1. Strength is the skill of a group of muscles to generate power during contractions. Muscle strength must be possessed by children early on. If the child does not have muscle strength, the child cannot perform physical play activities such as: running, jumping, throwing, climbing, hanging, and pushing;

2. Coordination is a skill to unite or separate in a complex task. Provided that coordination movements include the perfection of time between muscles and the nervous system. For example: the child in doing the throwing must have coordination of all the limbs involved. The child is said to coordinate his movement well if the child is able to move easily, smoothly in the circuit and the rhythm of his movement is well controlled;

3. Speed is a skill that is based on the abilities of a given time unit. For example: how far the distance traveled in a child to run four seconds, the farther the distance in the child, the higher the speed;

4. Balance is a person's skill to maintain the body in various positions. Balance is divided into two forms: static and dynamic balance. The static balance refers to maintaining the balance of the body when it stands somewhere. Dynamic balance is a skill to maintain body balance when moving from one place to another. He adds that static and dynamic balance is an oversimplification. In add two elements of complex balance and very specific in individual task and motion;

5. Agility is one's skill to change the direction and position of the body quickly and precisely when moving from point to point. For example: playing 
fishing fish, playing cat and rats, playing black, green the faster the time it takes to touch and the speed to dodge, the higher the agility.

Thus the elements applied in the playing of the boarding, board include: strength, coordination, and balance. These elements are required by the child during the activity of the walking bag on the board.

\section{Characteristics of Motor Development of Ages 5-6 Years (TK B)}

In choosing methods to develop children's motor skills, teachers need to adapt them to the characteristics of kindergarten children who are constantly on the move, hard to be quiet, have strong curiosity, enjoy experimenting and testing, are able to express themselves creatively, have imagination and love to talk (Sujiono, 2005). According to Bredekamp and Copple (Sujiono, 2005) children aged 5-6 years can already do the following activities:

1. Walking on the heels of your feet, on your toes, jumping irregularly, and running well;

2. Standing on one leg for 5 seconds or more, controlling the balance, standing on a 4 inch $(10.16$ $\mathrm{cm}$ ) beam, but having difficulty walking the $5 \mathrm{~cm}$ wide beam without seeing the foot;

3. Down stairs with legs alternately, can estimate foot ground;

4. Be able to overcome with adequate tempo rules and be able to play games that require quick reaction;

5. Begin to coordinate his movements when climbing or rolling on a small trampoline (screen cloth in the range to accommodate acrobats);

6. Shows increased endurance in longer periods, sometimes too excited and loses self-control in group activities.

The development of children aged 5-6 years is very rapid. At this age, children begin to develop new skills and improve the skills they already possess. This development is also shown by a good balance in climbing the beam / skis, jumping over objects, jumping well, jumping ropes, jumping and descending through stairs, climbing, coordinating swims, and even riding a bicycle.

\section{Aggression Behavior in Children}

Baron and Bryne (2000) define aggression behavior as a form of behavior intended to injure or harm other individuals who do not want the behavior to come. Based on these definitions obtained four notions of aggression, the first is aggression is a form of behavior is not emotional, the need for the second motive is the perpetrator of aggression has a purpose to harm the victim, the third is the victim of aggression that is a living thing is not an inanimate object, while the fourth is Victims of this aggression behavior do not want or avoid the behavior of perpetrators of aggression.

Based on several definitions put forward by experts can be drawn the general conclusion that the behavior of aggression is a form of behavior that is a reaction to frustration or inability to satisfy basic psychological needs intended to harm or injure living things or inanimate objects either physically or verbally, Either directly or indirectly.

\section{Dimensions of Aggression Behavior}

Buss states that aggression behavior can be classified into three dimensions: physical-verbal, active-passive and direct-indirect (Burchinal, PeisnerFeinberg, Pianta, \& Howes, 2002). The difference in the physical-verbal dimension lies in the difference between hurting the physical (body) of others and attacking with words. The difference in the passiveactive dimension is the difference between concrete action and failure to act, whereas direct aggression means face to face contact with the person being attacked and indirect aggression occurs without contact with the person being attacked. The combination of these three dimensions results in a framework for categorizing various Forms of aggression behavior, namely:

1. Direct active physical aggressive behavior. Acts of physical aggression by individuals / groups by dealing directly with other individuals / groups who become the target and direct physical contact.

2. Indirect physical actual aggression behavior. Acts of physical aggression committed by individuals / groups by not dealing directly with other individuals / groups who become the target.

3. Direct passive physical aggression behavior. Acts of physical aggression by other individuals / groups by dealing with other targeted individuals / groups but no direct physical contact.

4. Indirect passive physical aggression behavior. Acts of physical aggression by other individuals / groups by not dealing with other targeted individuals / groups and no direct physical contact.

5. Direct verbal aggression behavior. Verbal aggression acts committed by other individuals / groups by dealing directly with other individuals / groups.

6. Indirect verbal aggression behavior. Verbal aggression acts committed by other individuals / groups by not dealing directly with other individuals / groups who become the target.

7. Direct passive verbal aggression behavior. Acts of physical aggression by individuals / groups by dealing directly with other individuals / groups who become the target and direct physical contact.

8. Indirect physical actual aggression behavior. Acts of physical aggression committed by individuals / groups by not dealing directly with other individuals / groups who become the target.

9. Direct passive physical aggression behavior. Acts of physical aggression by other individuals / groups by dealing with other targeted individuals / groups but no direct physical contact.

10. Indirect passive physical aggression behavior. Acts of physical aggression by other individuals / groups by not dealing with other targeted 
individuals / groups and no direct physical contact.

11. Direct verbal aggression behavior. Verbal aggression, acts committed by other individuals / groups by dealing directly with other individuals / groups.

12. Indirect verbal aggression behavior. Verbal aggression acts committed by other individuals / groups by not dealing directly with other individuals / groups who become the target.

\section{Social Class}

Soekanto (2006) explains that in society there is something that is appreciated and every society there is something that is appreciated. Any valuable thing can be money or other economic value items, perhaps also land, science, power, religious piety, and possibly descent. Something that is appreciated is actually an embryo or seed that cultivates a multi-layered system, within the community. A higher appreciation of certain things will place them at a higher position than anything else.

Soeroso (2008) defines the social class as a stratum of persons of the same rank in the unity (sequence) of social status. This definition tells us that in society, there are people who are individually or together have more or less the same social standing.
They have more or less the same position will be in a more or less the same layer. The social positions of such persons shall be compared to those of others who have more or less equal social standing. Such a comparison would cause a group of people of the same rank to be above or below another group of people, then appear in the upper, middle, and lower social classes based on certain criteria.

From some of the definitions put forward by sociologists above can be concluded that the social class is the distinction of the population or society in the classes on a level (hierarchical), in which the class distinction in society is based on economic factors, education, employment and linkage status (position) of a family member with the status of another family member, when the family head position rises, then the status of other family members go up as well. The embodiment is the layers or classes of high, medium, or low classes. There are nine variables that determine a person's social status or class. According to Engel, Blackwell, and Miniard (2005) mentioned that there are nine variables that determine the status or social class of a person. The nine variables are classified into three categories, namely economic, interaction, and politics. The variables are: (1) work; (2) income; (3) wealth; and (4) education.

Table 13

Index of Sosial Status

\begin{tabular}{|c|c|}
\hline \multicolumn{2}{|l|}{ Occupation Scale (Weight of 4) } \\
\hline Description & Score \\
\hline Unemployed; housekeepers & 10 \\
\hline Students & 9 \\
\hline Pensioners; & 8 \\
\hline $\begin{array}{l}\text { Machine operators and semiskilled employees; employed in marginal semi-skilled } \\
\text { and unskilled jobs }\end{array}$ & 7 \\
\hline $\begin{array}{l}\text { Skilled employees - workers in manufacturing, retailing, catering and service } \\
\text { industries; bus and truck drivers, police and firefighters, etc. }\end{array}$ & 6 \\
\hline Administrative personnel (office workers), technicians and similar occupations & 5 \\
\hline Public school teachers, engineers, freelancers & 4 \\
\hline $\begin{array}{l}\text { Middle management, owners of small businesses, government officials, moderately- } \\
\text { successful professionals }\end{array}$ & 3 \\
\hline $\begin{array}{l}\text { Higher level business executives or managers, owners of middle-sized businesses (10- } \\
20 \text { employees), successful professionals }\end{array}$ & 2 \\
\hline $\begin{array}{l}\text { Government top officials, top corporate executives, leading-prominent professionals, } \\
\text { "rich" business owners (large business owners) }\end{array}$ & 1 \\
\hline \multicolumn{2}{|l|}{ Education Scale (Weight of 3 ) } \\
\hline Description & Score \\
\hline No education & 10 \\
\hline Incomplete elementary school & 9 \\
\hline Elementary school & 8 \\
\hline Skilled worker & 7 \\
\hline Secondary education & 6 \\
\hline Highly skilled worker & 5 \\
\hline College degree & 4 \\
\hline University degree & 3 \\
\hline Specialist & 2 \\
\hline Master, $\mathrm{PhD}$ & 1 \\
\hline \multicolumn{2}{|l|}{ Income Scale (Weight of 3) } \\
\hline Description & Score \\
\hline Up to $1000 \mathrm{KN}$ & 10 \\
\hline Up to $2000 \mathrm{KN}$ & 9 \\
\hline Up to $3000 \mathrm{KN}$ & 8 \\
\hline Up to $4000 \mathrm{KN}$ & 7 \\
\hline Up to $6000 \mathrm{KN}$ & 6 \\
\hline Up to $8000 \mathrm{KN}$ & 5 \\
\hline Up to $10000 \mathrm{KN}$ & 4 \\
\hline Up to $13000 \mathrm{KN}$ & 3 \\
\hline Up to $16000 \mathrm{KN}$ & 2 \\
\hline More than $16000 \mathrm{KN}$ & 1 \\
\hline
\end{tabular}

Source: Mihic dan Culina (2006) 


\section{Classification of Social Class}

Classification of social class in research using social position index (ISP) as stated in journal Mihic and Culina (2006) which of course modified and adapted to this research. Classification of social class using ISP is classification of social class which is based on three determinants namely work, education, and income. Each factor is weighted where the job factor is assigned a weight of number 4 as the main determinant of social class, education and income are weighted by number 3 . Each respondent is accorded a number of points classified into one member of the three classes (top, middle, and below). The formula for calculating the ISP index is as follows:

$\begin{aligned} \text { ISP score }= & (\text { Occupation score } x 4)+(\text { Education score } x \\ & 3)+(\text { Income score } x ~ 3)\end{aligned}$

The classification of social classes conducted by Mihic and Culina (2006) is as Table 13. Classification of social class conducted by Mihic and Culina (2006) with ISP score is then adopted and modified based on the context and location of research in Malang. The type of work, education is changed based on the standards and educational institutions in Indonesia while the income is modified based on the UMR located in the research area. The calculation is done by collecting a sketch of the three existing scales and the result multiplied by the score $(4,3,3)$. The score will classify a person in a high, medium, or low grade.

\section{CONCLUSION}

Conclusion: (1) there is a positive and significant influence of children's gross motor development against aggression; and (2) there is no indirect influence of gross motor development of children against aggression through social class of parents as intervening variable. Suggestions: (1) for parents should be able to provide stimulation in improving the motor development of children as well as providing stimulation in controlling child aggression through various social activities and play; and (2) for schools should develop a play program that can improve children's social.

\section{REFERENCES}

[1] Asher, S. R., L. C. Singleton, B. R. Tinsley, and S. Hymel. 2009. A Reliable Sociometric Measure for Preschool Children. Develop. Psychol., 15, 443-444.

[2] Baron, R. A., \& Byrne, D. 2000. Social Psychology. New York: Allyn \& Bacon.

[3] Barrow, H. M., and McGee, R. 1976. A Practical Approach to Measurement in Phisycal Education. New York: Lea \& Fibger.

[4] Crosby, F. J. 2004. Understanding Affirmative Action. Basic Applied Soc. Psychol., 15, 13-41.

[5] Davies, N.J. 2000. Chiropratic Pediatrics: A Clinical Handbook. New York: Harcourt Publisher.

[6] Depdiknas. 2007. Pedoman Pengembangan Fisik/Motorik di Taman Kanak-kanak. Jakarta: Depdiknas.

[7] Dunn, J. C. Dunn, J. G. H., and Bayduza, A. 2007. Perceived Athletic Competence, Sociometric Status, and Loneliness Elementary School Children. J. Sport Behav., 30, 249-263.

[8] Edwin, P. H. 1981. Principles and Method of Social Psychology. New York: Oxford University Press.

[9] Erwin, P. 2003. Friendship and Peer Relations in Children. New York: John Wiley and Sons Publishers.

[10] Gabbord, C.P. 2006. Lifelong Motor Development. New York: Brown and Benchmark Publishers.

[11] Gallahue, D. L., and Ozmun, J. G. 2006. Understanding Motor Development: Infants, Children, Adolescents, Adults. New York: McGraw-Hill Companies.

[12] Gulay, H. 2010. Peer Relationships in Preshool Period. Ankara: Pegema Publishing.

[13] Gunarsa. 2003. Psikologi Perkembangan Anak dan Remaja. Jakarta: PT BPK

[14] Hurlock, B. E. 2008. Perkembangan Anak. Jakarta: Erlangga.

[15] Irianto, D. P. 2002. Dasar Kepelatihan.Yogyakarta: State University of Yogyakarta.

[16] Johnson, J. E. 2009. Play and Early Childhood Development. New York: Addison Wesley Longman.

[17] Kostelnik, M. J., Whiren, A. P., Soderman, A. K., and Gregory, K. 2005. Guiding Children's Social Development: Theory to Practice. New York: Thomson and Demler Learning.

[18] Ladd, G. W., and Kochenderfer-Ladd, B. 2002. Identifying Victims of Peer Aggression from Early to Middle Childhood: Analysis of Cross-prevalance of Victimization and Characteristics of Identified Victims. Psychol. Assessment, 14, 74-96.

[19] Ladd, G. W., and Profilet, S. M. 2006. The Child Behavior Scale: A Teacher-Report Measure of Young Children's Aggressive, Withdrawn, and Prosocial Behaviors. Dev. Psychol., 32, 1008-1024.

[20] Morrison, G. S. 2000. Fundamentals of Early Childhood Education. New York: Merrill Prentice Hall, Inc.

[21] Mutohir, Cholik, T., and Gusril. 2004. Perkembangan Motorik pada MasaAnak-anak. Jakarta: Depdiknas.

[22] Ozer, D., and Ozer, M. 2004. Motor Development in Children. Ankara: Nobel Publishing.

[23] Patmonodewo, S. 2003. Pendidikan Anak Prasekolah. Jakarta: Rineka Cipta.

[24] Piek, J. P., Barrett, N. C., Smith, L. M., Rigoli, D., and Gasson, N. 2010. Do Motor Skills in Infancy and Early Childhood Predict Anxious and Depressive Symptomatology at School Age. Human Movement Sci., 29, 777-786.

[25] Ramaiah, S. 2003. Kecemasan Bagaimana Mengatasi Penyebabnya. Jakarta: Pustaka Populer Obor.

[26] Sadock, B.J., Kaplan, H. I., and Sadock, V. A. 2007. Kaplan and Sadock's Synopsis of Psychiatry: Behavioral Sciences / Clinical Psychiatry. New York: Lippincott Williams and Wilkins Publishers.

[27] Samsudin. 2005. Pengembangan Motorik di Taman Kanak-kanak. Jakarta: State University of Jakarta.

[28] Santrock, J. W. 2007. Psikologi Pendidikan. Jakarta: Kencana.

[29] Schoemaker, M. M., and Kalverboer, A. F. 2004. Social and Affective Problems of Children Who are Clumsy: How Early do they Begin. Adapted Phys. Activity Quarterly, 11, 130-140.

[30] Sears, P., and Taylor, S. E. 2015. Social Psychology. Los Angeles: Prentice Hall Internatonal, Inc.

[31] Shaffer, D., Schonfeld, I., O'Connor, P. A., Stokman, C., Trautman, P., and Shafer, S. 2005. Neurological Soft Signs: Their Relationship to Psychiatric Disorder and Intelligence in Childhood and Adolescence. Arch. General Psychiatry, 42, 342-351. 
[32] Sholeh, 2005. Psikologi Perkembangan. Jakarta: PT Rineka Cipta.

[33] Sigurdsson, E., VanOs, J., and Fombonne, E. 2002. Are Impaired Childhood Motor Skills a Risk Factor for Adolescent Anxiety: Results from the 1958 UK Birth Cohort and the National Child Development Study. Am. J. Psychiatry, 159, 1044-1066.

[34] Stott, D. H., Moyes, F. A., and Henderson, S. E. 2004. The Henderson Revision of the Test of Motor Impairment. San Antonio: Psychological Corporation.

[35] Sujiono, B. 2007. Metode Pengembangan Fisik. Jakarta: Universitas Terbuka.

[36] Sukamti, E. R. 2007. Diktat Perkembangan Motorik. Yogyakarta: State University of Yogyakarta.

[37] Sunardi, and Sunaryo. 2007. Intervensi Dini Anak Berkebutuhan Khusus. Jakarta: Ministry of National Education.

[38] Susanto. 2012. Perkembangan Anak Usia Dini: Pengantar dalam Berbagai Aspeknya. Jakarta: Kencana Prenada Media Group.

[39] Sutardjo, W. 2005. Pengantar Psikologi Abnormal. Bandung: Refika Aditama.

[40] To, T., Gadarette, S. M., and Liu, Y. 2001. Biological, Social and Environmental Correlates of Preschool Development. Child Care Health Dev., 27, 187-200.

[41] Ulrich, D. 2000. Test of Gross Motor Development: Examiner's Manual. Texas: PRO-ED.

[42] Williams, H. G., and Monsma, E. V. 2007. Assessment of Gross Motor Development. In Bracken, R., and Nagle, J., (Eds.)., Psychoeducational Assessment of Preschool Children. New York: Lawrance Earlbaum Publishers. 